\title{
A unique case of malignant pleural mesothelioma presenting with highly aggressive multiple brain metastases after a long disease-free period
}

\section{Agresif multipl beyin metastazları ile uzun süre hastalıksız izlem sonrası başvuran ender bir malign plevral mezotelyoma olgusu}

Asim Armagan Aydin', Furkan Bertug Cetin², Erkan Kayikcioglü ${ }^{1}$, Banu Ozturk ${ }^{1}$, Mustafa Yildiz ${ }^{1}$

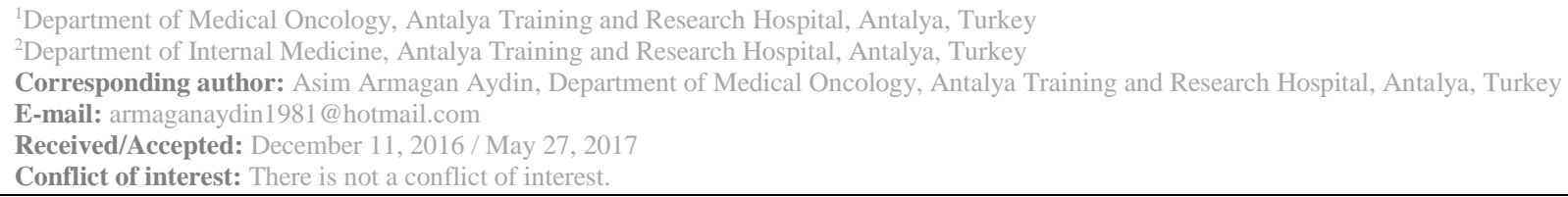

\section{SUMMARY}

Malignant pleural mesothelioma (MPM) is an uncommon, aggressive malignant neoplasm derived from the mesothelial cells of pleura or peritoneum characterized by poor outcome. Mesothelioma is thought to metastasize locally only via direct invasion and not have distant spread. Distant metastases are discovered mostly on post-mortem examination. However, recent post-mortem studies have identified metastases to the central nervous system (CNS) in about $3 \%$ of cases. A 55 year old patient presented with agressive multiple brain metastases after 4 years from the initial diagnosis. Palliative cranial radiotherapy was given because of unresectability of the lesions. The patient died 3 months after completion of radiotherapy. Distant metastase patern is not predictable in this disease, thus attention should be paid on the high-risk factors at initial presentation to prevent systemic relapses. Multimodality therapies have been produced longer survival times in this disease; clinicians should perform careful screening for brain metastasis in MPM, especially in patients with risk factors including younger age, advanced stage and non-epithelioid features.

Keywords: pleural mesothelioma, brain metastasis, brain radiotherapy.

\section{ÖZET}

Malign plevral mezotelyoma (MPM) nadir görülen plevra ya da peritondaki mezotelyal hücrelerden köken alan, kötü prognozlu, nadir ve agresif bir malign neoplazidir. Mezotelyomanın sadece lokal direkt invazyon yolu ile lokal olarak metastaz yaptığı; uzak yayılım yapmadığı düşünülmektedir. Uzak metastazlar post mortem incelemeler sonucu ortaya çıkmaya başlamıştır. Son zamanlarda yapılan post mortem çalışmalarda \%3 vakada santral sinir sistemi metastazları bildirilmiştir. 55 yaşında hasta ilk tanısından 4 yıl sonra çoklu agresif beyin metastazları ile başvurdu. Rezeksiyona uygun olmayan lezyonlar nedeniyle palyatif kraniyal radyoterapi verildi. Radyoterapinin tamamlanmasından 3 ay sonra hasta kaybedildi. Bu hastalıkta uzak metastaz paterni öngörülebilir olmadığ1 için, sistemik relapsları önlemede ilk tanı esnasında yüksek risk faktörlerine dikkat edilmelidir. Multimodal tedaviler bu hastalıkta daha uzun sağkalım sağlayabilmektedir. Klinisyenler MPM'de özellikle erken yaş, ileri evre ve epiteloid dışı özellikleri bulunan hastalarda beyin metastazı için dikkatli tarama yapmalıdırlar.

Anahtar sözcükler: plevral mezotelyoma, beyin metastazı, beyin radyoterapisi 


\section{INTRODUCTION}

MPM is highly aggressive and insidious neoplasm with a very poor prognosis that arises primarily from the surface serosal cells of the pleural, peritoneal and pericardial cavities. The disease is characterized by a long latency from the time of exposure to asbestos to the onset of disease, suggesting that multiple somatic genetic events are required for tumorigenic conversion of a normal mesothelial cell. Mesothelioma affects men in their $50 \mathrm{~s}, 60 \mathrm{~s}$, and $70 \mathrm{~s}$ due to 25 - to 40 -year latency period between occupational asbestos exposure and the development of the tumor ${ }^{1}$. Women and children can have the disease, but the male-tofemale ratio is approximately $4.5: 1^{2}$.

Malignant pleural mesothelioma usually presents with nonspecific pulmonary symptoms (chest pain, dyspnea, cough) due to the presence of extensive intrathoracic disease. Symptoms may be present for months or longer prior to diagnosis. Systemic symptoms such as fatigue and weight loss may also be present, particularly in patients with advanced disease. In rare cases, patients may present with a paraneoplastic syndrome or have symptoms from a paraneoplastic syndrome in combination with their pulmonary disease manifestations.

According to the International Association for the Study of Lung Cancer (IASLC) and the International Mesothelioma Interest Group (IMIG) data base, even if surgically treated; patients with stage I, II, III, and IV disease had median survivals of $20,19,16$ and 11 months, respectively ${ }^{3}$. The majority of patients with treated or untreated pleural mesothelioma die of complications of local disease because of increasing tumor bulk that eventually replaces the pleural effusion and causes progressive respiratory compromise, pneumonia, or myocardial dysfunction with arrhythmias; unrelenting chest wall pain requiring narcotics, which leads to cachexia; and/or dysphagia from tumor compression of the esophagus. Patients generally die of respiratory failure or pneumonia. Small bowel obstruction from direct extension through the diaphragm develops in approximately one-third of patients and $10 \%$ die of pericardial or myocardial involvement ${ }^{4}$.

Extrathoracic metastases occur late in the course of disease and are not usually the direct cause of the patient's death. In the largest series of patients with MPM who had autopsy, $54 \%$ to $82 \%$ had distant metastases, with the most frequently involved organs being the liver, adrenal gland, kidney, and contralateral lung ${ }^{5-6}$. Intracranial metastases are seen in approximately $3 \%$ of patients and are predominantly of the sarcomatous type ${ }^{6-7}$.

\section{CASE REPORT}

A 51 year-old man admitted to our hospital for investigation of intense dyspnea and non pleuritic chest pain that radiates into the back. These symptoms were evaluated by chest X-Ray and thoracic computed tomography. Computed tomography of the thorax revealed a right- sided pleural plaques with minimal pleural effusions. The PET-CT indicated an intense 18-FDG activity in the right lung.

Patient was diagnosed as a stage T4 tumour, unresectable malignant plevral mesothelioma. İitially the patient received radiation therapy and pemetrexed $500 \mathrm{mg} / \mathrm{m} 2$ plus cisplatin $75 \mathrm{mg} / \mathrm{m} 2$ for six cycles were given subsequently. At the end of the treatment there was no sign of extrapulmonary disease and the regular follow-up was planned according to NCCN guidelines.

The patient was admitted to emergency department with the complaints of speech dysfunction and weakness of left lower extremity. Neurological examination revealed a right spastic hemiparesis and nominal aphasia. Brain magnetic resonance imaging revealed multiple metastatic lessions in the brain parencyhma (Fig 1). ${ }^{18} \mathrm{~F}-\mathrm{FDG}-\mathrm{PET} / \mathrm{CT}$ showed stable disease (Fig 2) and there was no evidence of other primary tumour in the other sides. The arterial blood gas analysis indicated no abnormality. Histological findings were suggestive of an epithelioid type of malignant mesothelioma (Fig 3). Emergent cranial radiotherapy was given with anti-edema therapy. The patient died 3 months after completion of cranial radiotherapy. 

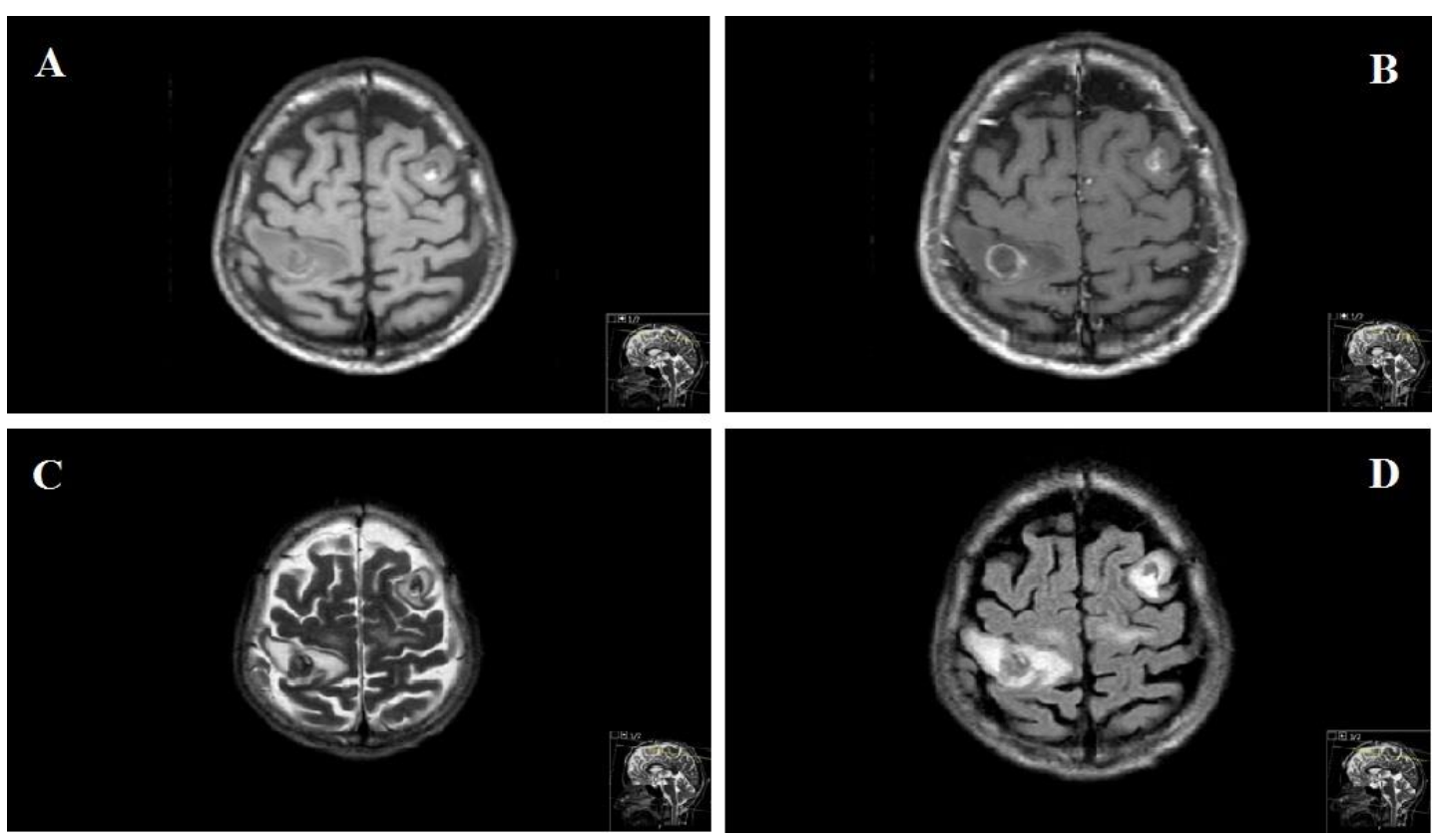

Fig 1. The largest was located in the postcentral gyrus of right parietal lobe ;T1 weighted images with hemoragic signal intensity, Metastatic lesions with peripheric contrast enhancement in post-contrast $\mathrm{t} 1$ weighted sequences, Heterogenous signal intensity on T2 weighted sequences, MRI Fluid-attenuated inversion recovery (FLAIR) with peripheral vasogenic brain edema (A: T1 axial, B: T1 postcontrast, C: T2 axial, D: T2 flair sequence)
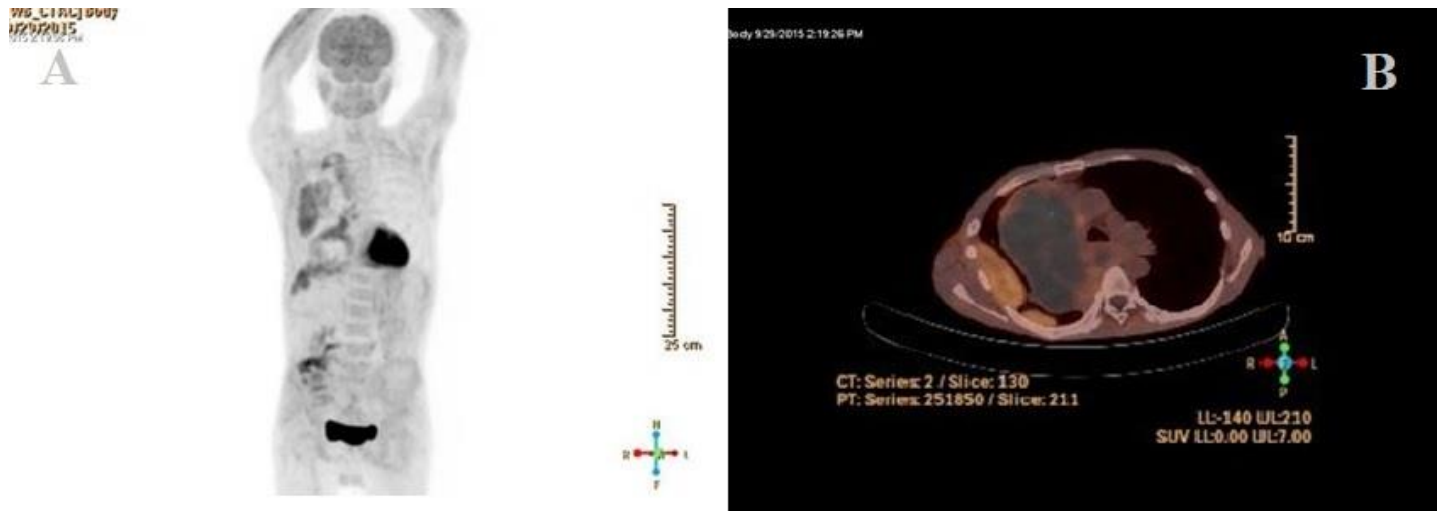

Fig 2. There was no pathological uptake of 18F-FDG except of lung (A-B)
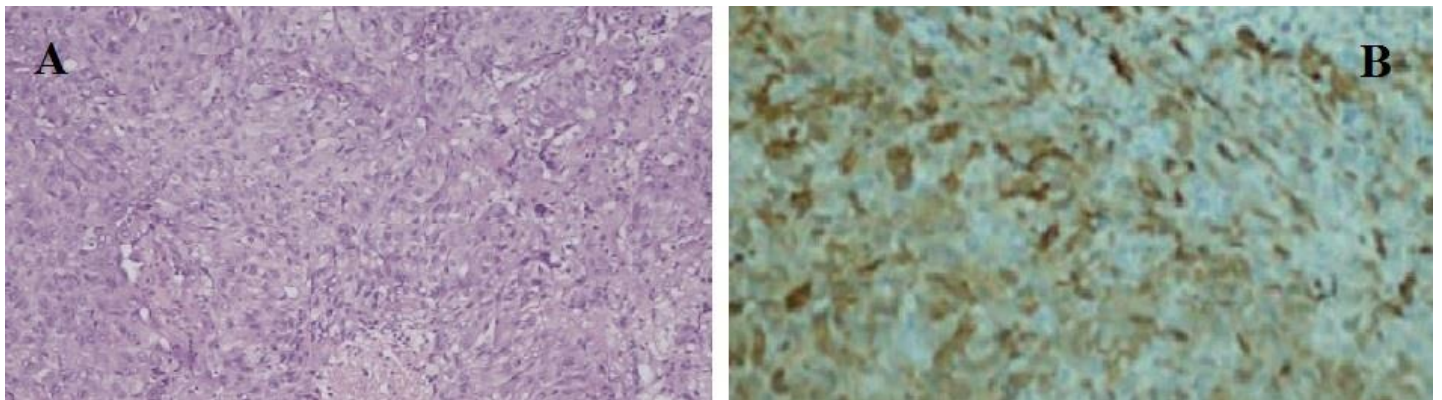

Fig 3. (A) large round epithelioid cells with large nuclei having moderate cytoplasm on hematoxylin-and-eosin (H\&E) staining, (B) Positive calretinin staining. 


\section{DISCUSSION}

Among the clinicopathological features of MPM, histological subtype is one of the most important factor influencing survival and sarcomatous histology is the most poor prognostic type ${ }^{8}$. Several studies suggested no difference in the rate of extra-thoracic dissemination among the histologic subtypes ${ }^{9-10}$. Yamagishi et al. showed that age $<65$ years and IMIG stage IV were both independently associated with brain metastasis as seen in the present case.

The incidence of CNS metastasis from malignant mesothelioma is not known. The majority of MPM brain metastases were reported in autopsy series $6,7,9,10$. Mesothelioma is often considered locally invasive and distant metastases are extremely rare, especially metastasis to the brain ${ }^{6}$. Previous studies have reported the presence of mesothelioma at distant sites, but the pattern and incidence varied among reports. Extrathoracic metastases occur late in the course of disease and are not usually the direct cause of the patient's death. Unfortunately, early detection of brain metastasis could not be practicable such as our patient.

A number of studies have reported intervention for cerebral metastases of MPM 11-14. Treatment strategies have been highly heterogeneous and overall survival has been poor despite aggressive management 11-14. Surgical resection of symptomatic solitary metastases can lead to symptomatic improvement and together with radiotherapy to local disease control. However, the published cases suggest that the cause of death usually surrounds progression of thoracic disease with effective symptom control from neurosurgical intervention. The median overall survival was found approximately 5 months even if surgical approach had been performed.

Overall survival was surprisingly very long in our case different from the naturel course until the occurrence of brain metastases. The disease recurrence occurred after a long silence period with multiple brain metastases in an acute neurologic situation. Lung disease was virtually stable comparing with clinical features and radiological involvement. Unresectable brain lesions were the most important factor on survival.

Although less common than intrathoracic, chest wall, intraperitoneal and abdominal wall metastasis, spread of malignant mesothelioma to the CNS may be an underappreciated yet important metastatic pattern of malignant mesothelioma. It should be considered to be aware of identifying CNS involvement in patients with new or changing neurologic symptoms because early identification may allow for palliative intervention and improve prolong survival. Furthermore, clinicians should perform careful screening for brain metastasis in MPM, especially in patients with risk factors including younger age, advanced stage and nonepithelioid features.

\section{REFERENCES}

1. Roggli VL, Sharma A, Butnor KJ, et al. Malignant mesothelioma and occupational exposure to asbestos: a clinicopathological correlation of 1445 cases. Ultrastruct Pathol 2002; 26: 55-65.

2. Wolf AS, Richards WG, Tilleman TR, et al. Characteristics of malignant pleural mesothelioma in women. Ann Thorac Surg 2010; 90: 949-56.

3. Rusch VW, Giroux D, Kennedy C, et al. Initial Analysis of the International Association For the Study of Lung Cancer Mesothelioma Database. J Thorac Oncol 2012; 7: 1631.

4. Antman KH, Blum RH, Greenberger JS, et al. Multimodality therapy for malignant mesothelioma based on a study of natural history. Am J Med1980; 68: 356-62.

5. Law MR, Hodson ME, Heard BE. Malignant mesothelioma of the pleura: relation between histological type and clinical behaviour. Thorax1982; 37: 810-15.

6. Falconieri G, Grandi G, DiBonito L, et al. Intracranial metastases from malignant pleural mesothelioma. Report of three autopsy cases and review of the literature. Arch Pathol Lab Med 1991; 115: 591-5.

7. Davies MJ, Ahmedzai S, Arsiwala SS, et al. Intracranial metastases from malignant pleural mesothelioma. Scand J Thorac Cardiovasc Surg1995; 29: 97-9.

8. Mansfield AS, Symanowski JT, Peikert T. Systematic review of response rates of sarcomatoid malignant pleural mesotheliomas in clinical trials. Lung Cancer 2014;86: 133-6. doi: 10.1016/j.lungcan.2014.08.017

9. Finn RS, Brims FJ, Gandhi A, Olsen N, Musk AW, Maskell NA, Lee YC. Postmortem findings of malignant pleural mesothelioma: a two-center study of 318 patients. Chest 2012; 142: 1267-73.

10. Yamagishi T, Fujimoto N, Miyamoto Y , et al. Brain metastases in malignant pleural mesothelioma. Clin Exp Metastasis 2015 DOI 10.1007/ s10585-015-9772-8

11. Kitai R, Kabuto M, Kawano H, Uno H, Kobayashi H, Kubota T: Brain metastasis from malignant mesothelioma--Case report. Neurol Med Chir (Tokyo). 1995, 35: 172-4. 
12. Wroński M, Burt M: Cerebral metastases in pleural mesothelioma: Case report and review of the literature. J Neurooncol 1993, 17: 21-6.

13. Mah E, Bittar RG, Davis GA: Cerebral metastases in malignant mesothelioma: Case report and literature review. J Clin Neurosci 2004; 11: 917-8.
14. Ishikawa $\mathrm{T}$, Wanifuchi $\mathrm{H}$, Abe $\mathrm{K}$, Kato $\mathrm{K}$, Watanabe A, Okada Y: Brain metastasis in malignant pleural mesothelioma presenting as intratumoral hemorrhage. Neurol Med Chir (Tokyo) 2010; 50: 1027-30. 